\title{
Extrinsic and intrinsic controls on mouth bar and mouth bar complex architecture: Examples from the Pennsylvanian (Upper Carboniferous) of the central Appalachian Basin, Kentucky, USA
}

DOI:

10.1130/B31429.1

\section{Document Version}

Accepted author manuscript

Link to publication record in Manchester Research Explorer

Citation for published version (APA):

Jerrett, R., Bennie, L. I., Flint, S., \& Greb, S. F. (2016). Extrinsic and intrinsic controls on mouth bar and mouth bar complex architecture: Examples from the Pennsylvanian (Upper Carboniferous) of the central Appalachian Basin, Kentucky, USA. Geological Society of America Bulletin, 128, 1696-1716. https://doi.org/10.1130/B31429.1

\section{Published in:}

Geological Society of America Bulletin

\section{Citing this paper}

Please note that where the full-text provided on Manchester Research Explorer is the Author Accepted Manuscript or Proof version this may differ from the final Published version. If citing, it is advised that you check and use the publisher's definitive version.

\section{General rights}

Copyright and moral rights for the publications made accessible in the Research Explorer are retained by the authors and/or other copyright owners and it is a condition of accessing publications that users recognise and abide by the legal requirements associated with these rights.

\section{Takedown policy}

If you believe that this document breaches copyright please refer to the University of Manchester's Takedown Procedures [http://man.ac.uk/04Y6Bo] or contact uml.scholarlycommunications@manchester.ac.uk providing relevant details, so we can investigate your claim.

\section{OPEN ACCESS}


Extrinsic and intrinsic controls on mouth bar and mouth bar complex architecture: examples from the Pennsylvanian (upper Carboniferous) of the central Appalachian Basin, Kentucky, USA

\author{
Rhodri M. Jerrett ${ }^{1}$, Laura I. Bennie ${ }^{1,2}$, Stephen S. Flint ${ }^{1}$, Stephen F. Greb ${ }^{3}$ \\ ${ }^{1}$ School of Earth, Atmospheric and Environmental Sciences, University of Manchester, Oxford Road, \\ Manchester, M139PL, U.K. \\ ${ }^{2}$ Current address: Wood Mackenzie Ltd., Exchange Place, 5 Semple Street, Edinburgh EH3 8BL, U.K. \\ ${ }^{3}$ Kentucky Geological Survey, University of Kentucky, Lexington, Kentucky 40506, U.S.A.
}

\title{
E-mail: rhodri.jerrett@manchester.ac.uk
}

Running title: Extrinsic and intrinsic controls on mouth bar architecture

Key words: mouth bar, delta, central Appalachian Basin, Pennsylvanian, Carboniferous.

Total words including figure captions and references: 10,760

\section{ABSTRACT}

A fundamental architectural element of deltas is the mouth bar. Although processbased facies models have been developed to reconstruct the influence of different external controls on mouth bar geomorphology, depositional architecture and grain-size distribution, few studies have documented the internal architecture of ancient mouth bars and mouth bar complexes, in order to analyse extrinsic and intrinsic controls on these parameters. Two exceptionally well exposed ancient examples show that the increasing influence of inertial forces in friction-dominated mouth bars result in the increasing deposition from gravity-flows (hyperpycnites and turbidites), with increasing bypass of the mouth bar foreset and deposition in a detached frontal lobe on the basin floor ahead of the mouth bar. The increasing influence of inertial forces also results in increased bed length, and the better development of clinothem bottomset beds. Within these friction-dominated mouth bars, following initiation and aggradationalprogradational growth, choking results in lateral accretion on the mouth bar flanks, but discharge may not be maintained symmetrically on both flanks. Additionally, "choking" of the feeding distributary can result in its upstream avulsion and abandonment of the mouth bar. This process generates laterally accreted fining-up successions which downlap on to floor of the receiving basin, contrasting with standard coarsening-up 
facies successions predicted for mouth bars. Within mouth bar complexes, superposition of individual mouth bars causes gradual shallowing of the water column, reducing gradients in, and increasing confinement of successive mouth bars. Hence, early mouth bars are more strongly inertia-influenced, flows have long run-out distances and are more likely to develop a succession of detached prodelta turbidite lobes. Later mouth bars are more strongly friction dominated and flows have short-run out distances since they are less able to achieve autosuspension. Earlier mouth bars display more "normal" aggradation-progradation, lateral accretion and retrogradation in an unconfined setting, whereas later mouth bars are more strongly confined and progradational. The two case studies illustrate that upward changes in mouth bar architecture and facies distributions within a mouth bar complex, are a predictable product of shallowing and increasing confinement during delta progradation.

\section{INTRODUCTION}

A fundamental architectural element of deltas is the mouth bar, that forms at the river mouth where fluvial outflow decelerates into a standing body of water and deposits the coarse fraction of its sediment load (Bates, 1953; Wright, 1977; Elliott, 1986). Mouth bars are constructed via the progradational addition of beds that dip (termed clinothems), fine and thin basinward, separated by surfaces (termed clinoforms; Rich, 1951) that typically demonstrate concave-up geometries with asymptotic toes. In plan view, mouth bars commonly have a lozenge or pear-shaped morphology, reflecting the lateral expansion of sediment laden fluid at the emergence point from a confined channel into the standing body of water. However, the cross-sectional geometry and scale of clinoforms, and plan geometry and scale of mouth bars vary, according to contrasts in temperature, salinity and suspended sediment load of the outflow relative to the receiving body of water, grainsize of the sediment load, water depth and sea-floor gradient of the receiving basin, and relative intensity of wave and tidal processes at the river mouth (Wright, 1977; Postma, 1990, 1995; Reading and Levell, 1996; Driscoll and Karner, 1999; Fielding et al., 2005). Progradation and aggradation of the mouth bar leads to coarsening-up successions, that have been extensively described in the geological record (see reviews by Bhattacharya, 2006, 2010). Mouth bar growth also decreases distributary channel discharge ("choking"), forcing bifurcation of the distributary channel around the mouth bar (Elliott, 1986; Olariu and Bhattacharya, 2006; Edmonds and Slingerland, 2007) or upstream avulsion and abandonment of the distributary channel (Bhattacharya, 2006). In either case, the active mouth bar will eventually become abandoned, and a new mouth bar forms at the new 
position of the distributary channel mouth. Multiple mouth bars stack compensationally to form mouth bar complexes.

A number of process-based facies models have been developed to reconstruct the interaction of extrinsic controls on the geomorphology, depositional architecture and grain-size distribution of ancient mouth bars. These models, largely based on analysis of vertical succession, have mainly emphasized the interplay of fluvial, wave and tidal processes, and drawn comparisons with modern "snapshot" plan-view analogues (e.g. Wright and Coleman, 1973; Coleman and Wright, 1975; Galloway, 1975; Miall, 1976; Orton and Reading, 1993; Elliott, 1986; Bhattacharya, 2006, 2010). An alternative classification developed by Bates (1953) and Wright (1977) in which mouth bars may be classified as inetia-, friction-, and buoyancydominated, according to the relative role of these competing forces acting on the incoming axial jet at the river mouth, has attracted little attention in the literature because these studies made no predictions about the expected bedforms and sedimentary structures produced in these different settings (Martinsen, 1990; Turner and Tester, 2006; and Ahmed et al., 2014, are notable exceptions). Outcrop studies naturally reflect the discontinuous and 2-D nature of most rock exposure, and little attention has also been directed at documenting internal variability within individual mouth bars during their evolution, and their stacking pattern within mouth bar complexes (e.g. Willis et al., 1999; Chidsey et al., 2004; Olariu and Bhattacharya, 2006; Fielding et al., 2006; Gani and Bhattacharya, 2007; Porebski and Steel, 2006; Enge et al., 2010; Ahmed et al., 2014).

The purpose of this study is therefore, firstly, to document the preserved internal architecture of ancient individual mouth bars and mouth bar stacking patterns within mouth bar complexes; secondly, to document systematic changes in depositional (and bypass) processes during the construction of mouth bars and mouth bar complexes; and finally, to reconstruct the extrinsic and intrinsic controls that resulted in the observed architecture. The study focusses on two mouth bar complexes from the Pennsylvanian (Upper Carboniferous) Breathitt Group of the central Appalachian basin, U.S.A.

\section{GEOLOGICAL SETTING AND STRATIGRAPHY}

Mouth bar complexes studied in this contribution occur in the Breathitt Group - a Morrowan - Desmoinesian (Namurian - Westphalian) fluvio-deltaic succession which comprises the majority of the central Appalachian foreland basin-fill (Fig. 1). The central Appalachian Basin was one of several broadly contemporaneous foreland depocentres formed to the NW of the Variscan-Alleghanian orogeny, from Alabama to the Czech Republic during the late Paleozoic (Thomas, 1976; Quinlan and Beaumont, 1984; Tankard, 1986), and were 
subsequently segmented by the opening of the Atlantic ocean in the Mesozoic. Throughout the Pennsylvanian, predominantly subarkosic siliciclastic debris was eroded from the orogenic hinterland to the southeast and transported transversely north-westward through the basin via a succession of deltas (Ferm and Cavaroc, 1968; Ferm, 1970; Horne et al., 1978; Rice et al., 1979; Chesnut, 1994). These deltas are largely considered to have been river-dominated (Englund and Thomas, 1990; Aitken and Flint, 1995), and more recently have been demonstrated to have been partially tidally modulated (Martino, 1994, 1996; Greb and Chesnut, 1996; Adkins and Eriksson, 1998; Greb and Martino, 2005). Lithospheric flexure towards the orogenic load in the south-east produced a markedly asymmetric basin-fill, and the maximum preserved thickness of the Breathitt Group in the Central Appalachian Basin is $1.5 \mathrm{~km}$ near the Kentucky-Virginia border (Wanless, 1975; Chesnut, 1992; Fig. 1A).

The Breathitt Group comprises a coarsening-up succession of marine, marginal marine and terrestrial clastic, coal and rare carbonate sediments, in which evidence for marine conditions generally decreases upwards (Horne et al., 1978; Chesnut, 1992, 1994). Chesnut $(1992,1996)$ formally subdivided the upper part of the Breathitt Group into the Pikeville, Hyden, Four Corners and Princess Formations, bounded by widespread, marine mudstone units - the Betsie Shale, Kendrick Shale, Magoffin and Stoney Fork Members (Fig. 2). Although there is some disagreement about the precise age of these four major marine units (c.f. Greb et al., 2009), paleobotanical studies suggest the Betsie Shale and Magoffin members represent the European $A$. vanderbeckei and A. aegiranum ammonoid biozones, which define the base and top of the Duckmanian/Westphalian B (c. 315-318 Ma; Gradstein et al., 2012) respectively. Hence, the major marine mudstone units have been interpreted as the maximum flooding zones of 1.5 Ma-duration (third-order sensu Mitchum and Van Wagoner, 1991) depositional sequences. Third-order marine mudstones coarsen upwards through heterolithic mouth bar successions, where they are not incised by lowstand sandstones. Between these major formation-bounding marine mudstones and the overlying, thick, coarsening-upwards successions, the strata comprise multiple 2-15 m thick cycles ("cyclothems") characterized by a locally-to-regionally developed marine to marginal marine mudstone which coarsens upward through heterolithic mouth bar and floodplain successions into a paleosol and regionally extensive coal or coal zone (Fig. 2). Commonly, much or all of the upper part of the cycle may be truncated by major erosionally-based fining-up fluvio-estuarine channel bodies which underlie the paleosol and regionally extensive coal (Chesnut, 1992; 1994; Aitken and Flint, 1994; 1995). 2-15 m thick cyclothems are each considered to represent c. $0.1 \mathrm{Ma}$ (Greb et al., 2008), and hence define fourth or fifth-order cycles (sensu Mitchum and Van Wagoner, 1991).

\section{METHODS AND DATASET}


Two mouth bar complexes were studied. The first, between two coals within the Fire Clay Coal zone, Hyden Formation (Fig. 2), is exposed along Kentucky Route 7 (Ky. 7) between Viper and Jeff, Perry County (Fig. 1C). The second occurs within the Betsie Shale, Pikeville

147 Formation (Fig. 2), and is exposed along U.S. Route 23 (U.S. 23) and side-roads between the Pikeville "cut-through", and Coal Run Village, (Fig. 1D). Ky. 7 provides a largely 2-D section through the mouth bar complex within the Fire Clay coal zone. The combination of U.S. 23 and side roads provide a more 3-D view of the mouth bar complex in the Betsie Shale. Facies and facies associations were described and interpreted by means of centimetre-scale sedimentary logging of km-scale road cut exposures. Paleoflow measurements were collected from trough and tabular cross bed foresets, asymmetric ripple crests and flute marks on the soles of beds. Additionally, dips and azimuths of bedding and fault planes were collected when eyed-in as significantly greater than $10^{\circ}$. Special attention was paid to measuring the limbs of synsedimentary folds, from which vergence could be determined. Vertical thicknesses were calibrated against road construction engineers' exploration boreholes, and vertical and lateral stratal relationships at the scale of individual road cut exposures were captured through the annotation of photomosaics. Correlation was confirmed by the identification of the regionally extensive mined coal seams (Chesnut, 1992, 1991; Rice and Hiett, 1994) from the relevant published 1:24,000 geological quadrangle maps (GQ343 - "Hazard South", GQ442 - "Broad Bottom" and GQ480 - "Pikeville"; Puffett, 1964; Alvord, 1965; Alvord and Holbrook, 1965). Key sedimentary logs collected through the two mouth bar complexes are reported in Appendix 1.

\section{FACIES ANALYSIS}

Nine facies associations (FA) are identified, based principally on grain size, sedimentary structures, trace and body fossil content, internal and external architecture (Table 1). These are, (1) Prodelta and off-axis fines of marine shelves or large embayments, (2) Fines of shallow lakes and small embayments, (3) Delta front and prodelta turbidite, (4) Distal mouth bar, (5) Proximal mouth bar, (6) Terminal distributary channel, (7), Subaerial crevasse splay and levee (8) Mire and (9) Trunk or distributary channel. Bioturbation intensity is typically low but variable. All facies associations have in common the pervasive occurrence of sand-grade mica flakes, clay flocs, and rare to abundant, finely comminuted plant debris, giving an overall "dirty" appearance to these rocks. Photographs of these facies associations are provided in Figure 3. 

above road level, in five road cuts between mileposts 0 and 3 (Fig. 1D). The zone is defined by two coals: the lower, main Fire Clay Coal seam, as much as $1.3 \mathrm{~m}$ thick, and an upper rider coal of the Fire Clay Coal zone (but not the next regionally extensive coal, which is formally named the "Fire Clay Rider Coal"; Fig. 2), up to $0.8 \mathrm{~m}$ thick (Fig. 4A). Paleoflow data and the architecture of the mouth bar indicate that the SW-NE oriented road cuts provide a 2-D oblique depositional strike section.

\section{Architecture}

At Location 7-2 (Fig. 4A and B) the mouth bar is up to $5 \mathrm{~m}$ thick, 300-500 m wide, and paleocurrent indicators are unidirectional towards the north. At the NE side of the exposure, the mouth bar comprises a c. $3 \mathrm{~m}$ thick coarsening-up succession from distal mouth bar deposits (FA4A) which rest directly on the main Fire Clay Coal, into proximal mouth bar deposits (FA5). This succession has a bidirectionally downlapping clinoform geometry, with downlap to the SW and to the NE, giving a concave-down cross-sectional view (Fig. 4B). At the NE side of the exposure, where bedding is horizontal relative to the main Fire Clay Coal, bedding surfaces within FA5 show erosional relief of up to $0.5 \mathrm{~m}$. This coarsening-up package is overlain sharply by a fining upward succession as much as $6 \mathrm{~m}$ thick, through FA4 into off-axis fines (FA2). To the SW, as bedding steepens relative to the main Fire Clay Coal, erosional relief at the bases of proximal mouth bar (FA5) beds decreases, and they pass gradationally into distal mouth bar strata (FA4A). The upper fining-up succession demonstrates a concave-up to weakly sigmoidal clinoform geometry with beds dipping and downlapping on to the main Fire Clay Coal to the SW, and offlapping older beds to the NE. These clinoform surfaces steepen to the SW as the succession fines, attaining dips of at least $5^{\circ}$ (given apparent dip). Beds in this fining-upward succession are thickest and coarsest grained at the base of the clinoform and thin up the foreset and down the bottomset. Sandstone bed lengths in the lower coarsening-up package are $>200 \mathrm{~m}$ but decrease to c. $100 \mathrm{~m}$ in the upper fining-up package. succession of subaerial crevasse splay and levee deposits (FA7) and the rider coal to the Fire Clay coal zone (FA8). At the NW end of the exposure, 2- $3 \mathrm{~m}$ of the upper part of the mouth bar has been removed by a concave-up scour surface at least $30 \mathrm{~m}$ wide which underlies the thin floodplain succession and the rider coal. The rider coal (FA8), and intercalated silt partings (FA7) thicken from c. $0.4 \mathrm{~m}$ to $0.8 \mathrm{~m}$ into the axis of the scour. Lateral to the mouth bar, at the SW end of Location 7-1 and at 7-3, the equivalent section is represented by 1-2.5 m thick deposits of off-axis fines (FA2) that are organic-rich and canneloid. 

multi-storey trunk or distributary channel-fill (FA9) sand bodies which cut down from within the Fire Clay Coal zone and amalgamate with a similar multi-storey sand body which underlies the Fire Clay Coal zone. To the NE, at Location 7-1, the channel-fill (FA9) succession comprises two storeys, the lower of which is c. $10 \mathrm{~m}$ thick and markedly heterolithic in its fill. Large-scale accretion surfaces and growth faults within this storey dip towards the SE, and paleoflow indicators within this storey are bimodal towards the SE and NW. A succession of fining-up subaerial levee deposits (FA7) as much as $3 \mathrm{~m}$ thick thins and fines to the SW, away from the margin of the multi storey sand body. Bedding surfaces within FA7 pass into off axis fines (FA2) over a lateral distance of $200 \mathrm{~m}$. To the SW, at Location 7-5, a similar fining-up succession of subaerial crevasse splay and levee deposits (FA7) up to $7 \mathrm{~m}$ thick, also thins and fines into off axis fines (FA2) towards the NE, away from the margins of the major channel-fill succession (FA9). The precise termination of the subaerial levee deposits into fines is not exposed, but occurs across a distance of less than $0.7 \mathrm{~km}$.

\section{Interpretation and depositional model}

Figure 5A-E provides a paleogeographic reconstruction of the evolution of the mouth bar. Its maximum thickness of $5 \mathrm{~m}$ indicates that it prograded into a body of water that was at least this deep. The 1-2.5 m-thick FA2 fines, lateral to the mouth bar at Location 7-1 and 7-3, reflect differential compaction of the clay-rich sediment relative to the sand, and probable lateral shallowing of the paleo-water depth. The highly organic-rich, canneloid nature of these fine grained sediments suggests the water was of low $\mathrm{pH}$ and fresh. Paleoflow data, and an absence of wave ripples or indicators of tidal reworking suggest the mouth bar represents a fluvially-dominated end-member.

The lower, coarsening up succession rests directly on the main Fire Clay coal, suggesting mouth bar initiation was rapid after drowning of the peat substrate. The exposed geometric maximum between the oppositely downlapping clinoforms at the top of the coarsening-up succession (Fig. 4B) reflects the position of maximum progradation and aggradation of the mouth bar axial crest (i.e. the locus of deposition). Assuming a strike-symmetrical geometry, the mouth bar had, by this stage, evolved into a positive topographic feature at least $3 \mathrm{~m}$ high, and 300-400 m wide across depositional strike (Fig. 5A-B). The upper, fining-up succession, with reduced sandstone bed lengths, represents progressive abandonment of the mouth bar. The downlap of beds on to the main Fire Clay Coal to the west, and offlapping relationship against older beds to the northeast, reflect lateral, compensational accretion of the mouth bar towards the west (Fig. 5C-D). Such lateral accretion of mouth bars has been described from the 
modern Atchafalaya Delta by Van Heerden and Roberts (1988) and Olariu and Bhattacharya (2006).

The scour that removes up to $3 \mathrm{~m}$ of the upper mouth bar at the NW end of the exposure suggests the feeding channel avulsed to the east at the end of the lifetime of the mouth bar (Fig. 5E). The channel at this stage was up to $3 \mathrm{~m}$ deep and more than $30 \mathrm{~m}$ wide. This feature was short-lived and dominated by the bypass of sediment, since little or no clastic material is present within the channel. After abandonment of the entire mouth bar, peat accumulated preferentially in the abandoned channel, onlapped its margins, and expanded across the newly emergent flood plain to form the rider coal.

The depth of the basin receiving the sediment (c. $5 \mathrm{~m}$ ) was not much greater than the depth channel feeding the mouth bar (c. 3 m). Consequently, the relief of the basin would have not been sufficient for the incoming plume to descend and become hyperpycnal. Evidence in the form of, (1) the limited extent of beds, which pass rapidly down-dip from proximal (FA5) to distal (FA4A) mouth bar deposits, and downlap on to the Fire Clay Coal across a distance of less than $200 \mathrm{~m}$; (2) the occurrence of cross bedding in FA5, and (3) the clay-grade nature of fines (FA2) lateral to the mouth bar at Locations 7-1, 7-2 and 7-3, is indicative of sustained flows at the distributary mouth, the inertia of which was overcome over short distances (c. $200 \mathrm{~m}$ ) by bed friction, resulting in rapid deposition of the sediment load (i.e. it was a friction dominated mouth bar). Because hypopycnal flows are, by definition, buoyancy-dominated (Wright, 1977), incoming flows which generated this mouth bar must have been homopycnal. Homopycnal inflow, and friction-dominance would be expected in such a setting, where the receiving basin is shallow relative to the thickness of the incoming turbulent flow, such that the flow expands laterally, increasing the relative influence of turbulent bed friction upon it (Wright, 1977). In this example, rapid deposition of the fine fraction of any suspended sediment may also have been aided by flocculation in the low pH conditions (e.g. Staub and Cohen, 1978).

The lower storey in the multi storey succession of traction-load trunk or distributary channel-fills (FA9) at Locality 7-1 is considered to be broadly coeval with, or a little older than the mouth bar. This is because the subaerial levee deposits (FA7) that fine away from the channel-fill grade upward and towards the SW into FA2 fines (Fig. 4A). Since FA2 fines in turn grade from the mouth bar, it is logical that the lower storey in the multi storey channel is either older than, or coeval with the mouth bar. A similar relationship can be determined from FA7 at Location 7-5 (not shown on Fig. 5), which also grades upward and laterally into FA2. However, these subaerial levee deposits are truncated by a younger FA9 storey, and cannot be matched to the deposits of the channel that existed at that time (Fig. 4A).

The development of these channel-levee complexes may have contributed to the mechanism of confinement for the standing body of water into which the mouth bar prograded 
(i.e. an interdistribuatry lake or embayment), although the height of the levees (a maximum of c. $3 \mathrm{~m}$ at Location 7-1, close to the contact with the FA9 channel) is less than the total thickness of sediment accumulated in the mouth bar complex $(5 \mathrm{~m})$. The mouth bar complex was deposited where the Fire Clay Coal is at its thickest (1.3 $\mathrm{m}$ at Location $7-2$, compared with $<1.0 \mathrm{~m}$ at all other localities). Peat is one of the most compactable sediments (Ryer and Langer, 1980), and much of this compaction happens through early passive dewatering during the accumulation of peat (Nadon, 1998; Van Asselen et al., 2009, 2010), suggesting that differential compaction of the underlying peat may have contributed local accommodation for the accumulation of the mouth bar.

Overall, the scale of this mouth bar, c. 600-800 m along depositional strike, and $5 \mathrm{~m}$ thick, and its depositional context, adjacent to a broadly coeval major trunk or distributary channel, suggests that it belongs to a "crevasse delta" (e.g. Coleman and Gagliano 1964; Arndorfer 1973; Fielding 1984, 1987; Tye and Kosters 1986; Pulham 1989; Tye and Coleman 1989; Roberts 1997; Gugliotta et al., 2015). It represents a fluvially-dominated end-member. The inflow was largely homopycnal, due mainly to a relatively shallow water depth which inhibited the formation of hyperpycnal underflows. The dominance of frictional deceleration of the flow at its base led to rapid sedimentation and the formation of short bed lengths which downlap abruptly on to the underlying substrate. This mouth bar should be considered frictiondominated, although the accumulation of organic-rich fines on the margins of the mouth bar are probably indicative of a component of hypopycnal outflow (i.e. there was a component of buoyancy-influence).

\section{MOUTH BARS IN THE BETSIE SHALE, U.S. 23 AND SIDE ROADS, PIKE COUNTY}

In Pike County, the Betsie Shale is exposed at road level: (1) for c. $6 \mathrm{~km}$ in 12 road-cuts along U.S. 23, between the Pikeville "cut-through" in the S, and Coal Run Village in the N, between mileposts 24 and 28; (2) for c. $1.5 \mathrm{~km}$ in five road-cuts along Stone Coal Road (Ky. 3227 ) between mileposts 0 and 1; and (3) for c. $2 \mathrm{~km}$ in five road-cuts along U.S. Route 119 (U.S. 119), between mileposts 1 and 2 (Fig. 1D; Fig. 6). The Betsie Shale is defined by two coals (FA8); the upper coal of the Bingham Coal zone, and the lower coal of the Lower Elkhorn Coal zone (Chesnut, 1991). The entire stratigraphic section is exposed in the south of the study area (e.g. Location 23-11), and is approximately $50 \mathrm{~m}$ thick. Paleoflow data (Fig. 6A) and the architecture of the mouth bar complex indicate progradation towards the NW or WNW. Paleocurrents in prodelta turbidites (FA3) are unimodal towards the W, whereas those from thin-bedded and tidally modified density-flow and traction-load deposits are bimodal towards the E-NE and SW. Hence the S-N oriented U.S. 23 road-cuts provide an oblique depositional strike section view 
through the complex, whereas the SW-NE oriented Ky. 3227 road cuts and the WSW-ENE oriented US. 119 road-cuts are oblique dip-sections.

\section{Architecture}

The correlation panels suggest that three mouth bars (MB1-3) are partly exposed in the Betsie Shale. In oblique strike view along U.S. 23 (Fig. 6C), MB1 comprises three coarsening-up successions (MB1a-c). The lower coarsening-up succession, MB1a, is composed of 10-15 m of prodelta fines (FA1) above the Bingham Coal, that pass upward into prodelta turbidites (FA3). When restored to paleohorizontal, beds in MB1a show apparent dips to the $N$, of $<1^{\circ}$, but insufficient exposure prohibits the determination of the clinoform geometry. Above this, a second, c. 40 m coarsening-up succession, MB1b, comprises prodelta fines (FA1) that pass upward through prodelta turbidites (FA3), into a succession of distal mouth bar deposits (FA4), interstratified with terminal distributary channels (FA6) and capped by proximal mouth bar deposits (FA5). Beds in MB1b show apparent dips to the $\mathrm{N}$ at $<1^{\circ}$ in the lower part, increasing to c. $5^{\circ}$ in the $10 \mathrm{~m}$ of the coarsening-up succession. At location 23-11, a sigmoidal clinoform geometry is evident in MB1b, as apparent bedding dips decrease to $<1^{\circ}$ below the Lower Elkhorn Coal (Fig. 6D). Paleocurrent indicators in MB1a and MB1b are towards the NW. Correlations indicate that FA4 and 5 pass down clinoform into FA1 and 3, although individual beds cannot be traced between road cuts 23-11 and 23-6 to 23-10. Between locations 23-6 and 23-5, MB1b bottomsets are truncated, and offlapped by MB1c, a coarsening-up succession $>20$ m thick of prodelta fines (FA1) and turbidites (FA3) that pass upward into distal mouth bar deposits (FA4A). Clinoforms in MB1c have a concave-up geometry, with beds thickest and coarsest at the base of the foreset, with fining and thinning up foreset and towards the bottomsets. Paleoflow indicators in MB1c are towards the S. In oblique dip view, along U.S. 119, the top of MB1c is exposed. Apparent bedding dips are horizontal relative to the overlying Lower Elkhorn Coal, and increase to $<1^{\circ}$ to the WNW.

MB2 comprises a coarsening-up succession, followed by a fining-up succession that exceeds 20 m thickness. In the coarsening-up succession, prodelta fines (FA1) pass upward into a complexly interstratified succession of distal mouth bar (FA4) and proximal mouth bar (FA5) deposits, and terminal distributary channel-fills (FA6). A single, well developed unit of cyclic rhythmites (FA4B) occurs within the distal mouth bar deposits (Fig. 6C). The upper fining-up succession is represented by a return from proximal mouth (FA5) to distal mouth bar (FA4). In strike view, along U.S. 23 (Fig. 6C), MB2 displays a concave-up clinoform geometry to the north, which becomes a sigmoidal geometry southwards. It is not clear whether this change in geometry is of depositional origin, or due to progressively deeper top-truncation beneath 
subaerial crevasse splay and levee deposits (FA7) underlying the Lower Elkhorn Coal. Foresets display apparent dips of $2^{\circ}$, increasing to $3^{\circ}$ towards the south, and short, relatively steep bottomsets that downlap to the south on to the upper surface of MB1, which displays an apparent dip to the N. Topsets and upper foresets of MB2 comprise FA4, 5 and 6. Bed thickness, grainsize and degree of scouring at the bases of beds decrease down foresets, and the lower foresets and bottomsets comprise FA1 and FA4. Across strike, paleoflow is to the N or NW in the upper foresets to the north (Location 23-1), and towards the NE in the lower foresets to the south (locations 23-2 and 23-3). A subordinate, but significant number of readings indicate paleoflow to the SW. In depositional dip view, along Ky. 3227, the upper forests of MB2 display an oblique parallel clinoform geometry with foresets dipping at 2-3 ${ }^{\circ}$ to the SW at 3227-1 to $3227-4$, increasing to $20^{\circ}$ at $3227-5$. The absence of topsets and the parallel geometry is ascribed to later top-truncation. The succession comprises the same facies associations as in strike view, and the same prominent interval of cyclic rhythmites (FA4B) as seen along U.S. 23 is exposed. A discrete interval of dish-and-pillar-structures, with apparent fold vergence to the NW occurs within FA5. Paleoflow azimuths are broadly parallel to foreset dip, but the majority are oriented up-dip, to the SW, with a minority oriented down-dip, to the NE.

In strike view, along U.S. 23 (Fig. 6C), MB3 comprises, c. 15 m of prodelta fines (FA1) that pass upward into distal mouth bar deposits (FA4). These are truncated by erosively-based proximal mouth bar (FA5) and subaerial crevasse splay and levee (FA7) deposits. Clinoform surfaces in strike view are concave-down, top truncated, and have apparent dips to the N, which downlap or onlap against the top of MB2. The oblique depositional dip view through MB3 reveals a similar facies succession, and a distinct interval of soft sediment deformation, with apparent fold vergence to the WNW and well-developed angle-of repose cross strata with asymptotic bottomsets. The thickness of MB3 increases from c. $10 \mathrm{~m}$ up dip to c. $30 \mathrm{~m}$ down dip, as clinoform bottomsets downlap on to the easterly dipping upper surface of MB1 and MB2. Clinoforms have a parallel geometry and dip by c. 2-30 to the ESE, and have short bottomsets (Fig. 6I). These evolve into a more concave-down geometry to the WNW, with foresets dipping c. 4-5 ${ }^{\circ}$ and longer bottomsets. The concave-down geometry is the results of the top-truncation of top sets beneath subaerial crevasse splay and levee deposits (FA7) which underlie the Lower Elkhorn Coal.

\section{Interpretation and depositional model}

Figure 7 provides a paleogeographic reconstruction of the evolution of the mouth bar complex in the Betsie Shale. The Betsie Shale is approximately $50 \mathrm{~m}$ thick, setting a minimum water depth into which the mouth bar complex prograded. Facies and paleoflow data suggest 
that the mouth bar was subject to tidal influence, as interpreted in a succession of mouth bars developed in the younger Magoffin Shale in the Four Corners Formation of the Breathitt Group (Adkins and Eriksson, 1998; Fig. 2).

The lower coarsening-up succession, MB1a, is interpreted as a detached frontal lobe which prograded ahead of the main mouth bar, MB1. It is interpreted as such because bedding orientations place this succession in the clinoform bottomset, and it is overlain by a succession of FA1 prodelta fines at the base of MB1b (Fig. 7A), which forms the base of the MB1 mouth bar sensu stricto. Detached frontal lobes have also been described by Martinsen (1990), Mutti et al. (2003) and Ahmed et al. (2014). The normally-graded FA3 beds in MB1a (i.e. Tc-Te turbidite subdivisions of Bouma, 1962) are the product of deposition from underflows that had sufficient density, inertia and run-out distance to achieve autosuspension. The latter were provided by a sufficiently long, steep slope. The length and gradient of this slope cannot be determined as it is not exposed, but it was of the order of several kilometres long. The origin of these turbidites may have been oversteepened MB1 clinoform forests up-dip, that failed and ignited submarine slides which transformed into density currents (e.g. Parker, 1982; Emms, 1999). These density currents were sufficiently energetic for bypass of the mouth bar foreset, leading to deposition on the basin floor. Alternatively, the density contrast between the effluent discharge at the river mouth and the ambient water body may have been sufficient such that the flows became hyperpycnal. Under these circumstances, the inertia of the underflows, provided by high discharge (possibly during flood stage only), and maintained by high slope gradients at the distributary mouth, would have needed to have been great enough for a proportion of the sediment to bypass the mouthbar foreset and deposit on the basin floor in front. Hyperpycnal flows occur most commonly in fresh water settings, because marine waters are denser than fresh water and buoy the fresh fluvially derived effluent. The occurrence of lingulid brachiopods in the Betsie Shale in the study area (Alvord and Holbrook, 1965), may be indicative of marine to brackish water, but the progradational sediment package, general paucity of fully openmarine fauna, lack of significant bioturbation, may all indicate significant fresh-water flushing during progradation (Bhattacharya and MacEachern, 2009). Hyperpycnal flows in marine settings have been documented when suspended sediment densities greater than c. $25 \mathrm{~kg} / \mathrm{m}^{3}$ are input into the receiving body of water (Mulder and Syvitski, 1995; Wright and Friedrichs, 2006; Lamb and Mohrig, 2009).

The apparent northward dip of clinoforms in MB1b implies downlap on to the MB1a frontal lobe, and a component of lateral accretion during growth of the mouth bar (Fig. 7B-C). In the topset and upper foreset of MB1b, the predominance normal, inverse inverse-normal and a lack of grading in FA4 beds is characteristic of deposition in a system that was responding strongly to waxing and waning of the fluvially-derived input, although there is uncertainty 
whether these were the products of homo- or hyperpycnal flows, or some of each. Scour surfaces within FA4, but more especially at the base of FA5 and FA6 are also indicative of erosion and sediment bypass, suggesting some of the flows were hyperpycnal. The development of cross bedding in the coarser deposits of FA5 and 6 that are interstratified with FA4, is indicative of sustained bedload transport, and substantial frictional deceleration, but both homo- and hyperpycnal flows will experience bed friction (Ahmed et al., 2014). The occurrence of bidirectional paleoflow indicators and rhythmic bedding in FA4b implies the influence of tides on the system; the acceleration, dampening or reversing of fluvially-derived inflow, lessening of the density gradients between the incoming and ambient flow at the river mouth, and the reworking of already deposited sediment or reactivating their associated bedforms (Wright, 1977; Dalrymple, 2010). The down-clinoform transformation of FA4 into FA3 turbidites in MB1b suggests that a proportion of FA4 beds were the products of hyperpycnal flows, which were provided with sufficient run-out distance and gradient to promote autosuspension, and for the denser part of the underflow to overtake the less dense portion, and generate normally graded beds (e.g. Mulder et al., 2003). Based on the cross section in Figure $6 \mathrm{D}$, this slope was at least $2-3 \mathrm{~km}$ long, with a maximum gradient of at least 5o. MB1b bottomsets between locations 23-6 and 23-5 were scoured, and subsequently onlapped by MB1c as lateral, NW-directed accretion of MB1 continued. The scour attests to erosion and further sediment bypass in MB1 at this time. However, if any detached frontal lobes formed ahead of the mouth bar at this time, they are not exposed in the plane of section exposed by the road cuts documented in this study. The downlap surface of MB2 on to MB1 represents the position of maximum progradation of MB1. The position of the clinoform rollover or toptruncation of topset to this downlap surface is not exposed, but its projected position (Fig. 6C) suggests that the mouth bar top may have by this stage grown to more than $1 \mathrm{~km}$ across depositional strike (Fig. 7C).

Wright (1977) suggested that for a mouth bar to be classified as inertia-dominated, hyperpycnal flows must be supercritical. No evidence is observed for supercritical bedforms such as antidunes or humpack dunes anywhere in MB1, so the mouth bar cannot necessarily be interpreted as "inertia-dominated". However, the interpreted bypass and autosuspension of turbulent flow, and deposition of beds with lengths that exceed many hundreds of meters, suggest the flows had more inertia than, for example, the mouth bar in the Fire Clay coal zone, and mouth bars in the upper part of the Betsie Shale Mouth Bar Complex (see below). The inertia of these flows were able to exceed and resists turbulent bed friction and turbulent diffusion over distances of several kilometers.

MB1 was abandoned, and MB2 prograded from the SW, into the unfilled accommodation north of MB1. Bar accretion was directed towards the NE, oblique to paleocurrents, and MB2 
bottomsets downlapped and onlapped the foresets and bottomsets of MB1 (Fig. 7D). Hence,

468 MB2 prograded into a body of water that was shallowed by deposition of the older mouth bar.

469 As with the mouth bar in the Fire Clay Coal zone, the lower coarsening-up succession in MB2

470 represents progradation of the mouth bar, whereas the upper fining-up succession represents

471 its gradual abandonment, and the back-stepping of the locus of sediment deposition (Fig. 7E). In

472 MB2, mouth bar and terminal distributary channel facies do not pass down-clinoform into delta

473 front turbidites, and clinoforms have relatively short bottomsets where they downlap onto MB1.

474 As with MB1, the dominant type of outflow in MB2 is not clear. Incision of FA4 by subaqueous

475 channelized elements of FA6 most likely represent short episodes of bypass followed by

476 backfilling, caused by plunging hyperpycnal flows associated with increased discharge at the

477 river mouth. Hyperpycnal flows were, however, unable to attain autosuspension. The shallower

478 water and decreased length of clinoform slope, to c. $1 \mathrm{~km}$ or less, promoted lateral expansion of

479 the incoming plume, increasing interference with the sediment interface, and was not conducive

480 to maintenance of plume inertia. The plume jet rapidly decelerated, and deposited over just a

481 few hundreds of meters. Normal, inverse, or a lack of grading in FA4 beds were a response to waxing and waning of the fluvially-derived outflow, which may also have been modulated by the effects of tides. The bypass surfaces at the base of FA6 channels cannot be traced with confidence down-dip into deposits, but it is proposed that no detached frontal lobe would have formed ahead of MB2 because the system was more friction dominated at this stage, and the incoming plumes had reduced run-out length for maintenance of their inertia.

In both depositional dip and strike view, the gradual steepening of clinothem foresets in MB2 represents gradual steepening of the mouth bar front. The downlap surface of MB3 on to MB2 represents the position of maximum progradation of MB2. At the time of abandonment, MB2 mouth bar top had a length of more than $1 \mathrm{~km}$ across depositional strike (Fig. 7E).

Following abandonment of MB2, MB3 prograded in a NE direction into the unfilled accommodation between MB1 and MB2. Bathymetry was strongly controlled by the previous deposits of MB1 and MB2, and the increase in (undecompacted) thickness of MB3 from c. $10 \mathrm{~m}$ to $30 \mathrm{~m}$ down dip, along U.S. 119 reflects the sea floor gradient across which MB3 was prograding. Similarly to MB2, delta front turbidites are absent from MB3 in the study area, consistent with deposition in relatively shallow water compared to earlier mouth bars. The paleogeographic reconstruction implies that the vector of mouth bar progradation was strongly downstream, relative to MB1 and MB2 which display strong lateral as well as axial accretion components. Proximal mouth bar sediments (FA4) in the upper part of MB3 display strong erosion into the distal mouth bar sediments (FA3), also suggesting deposition in a more confined setting. 
503 be considered more friction dominated than MB1. However, the presence of subaqueous

504 terminal distributary channels in both suggested that flows were able to become hyperpycnal,

505 at least episodically, and the the mouth bars can therefore be considered more inertia-

506 influenced than the mouth bar in the Fire Clay coal zone.

$507 \quad$ No major distributary channel is observed flanking the margins of any of the mouth bars

508 in the Betsie Shale, although the large number of amalgamated terminal distributary channels

509 that cap the coarsening up succession in MB2 at locations 23-1 to 23-2, suggest the trunk

510 distributary channel may have been located very near-by; perhaps just up depositional dip.

511 However, it appears that all three mouth bars were abandoned by avulsion of the distributary

512 channel up stream before it was able to prograde into the study area.

513 The scale of the mouth bars in the Betsie Shale, exceeding 20-30 m thick, and with

514 clinoform foresets extending over more than $1 \mathrm{~km}$, suggests that this complex represents major

515 delta front progradation into the "Betsie Shale Seaway". The mouth bars in the complex were

516 fluvially dominated, but tidally modulated. Whether outflow was dominantly homo- or

517 hyperpycnal is not clear. However, plunging hyperpycnal flows did develop, especially in MB1,

518 where they were able maintain sufficient inertia to bypass the mouth bar foreset and deposit a

519 frontal lobe on the basin floor. Later mouth bars MB2 and MB3 also show evidence episodic

520 hyperpycnal flows, but no frontal lobe was developed in these cases, true normally-graded

521 turbidite successions did not develop, and bed lengths were reduced, indicating the increased

522 dominance of frictional processes in these mouth bars. All mouth bars in the Betsie Shale are

523 considered friction dominated, because there is no evidence for the development of

524 supercritical bedforms in the succession. However, MB1 was more strongly influenced by

525 inertial forces than MB2 and MB3, and this was a function of the decreasing bathymetry, of the

526 "Betsie Shale Seaway".

527

528

\section{DISCUSSION AND SUMMARY}

529

Analysis of these Breathitt Group mouth bar examples contributes to a small, but growing number of outcrop-based studies of internal mouth bar architecture and mouth bar complex stacking patterns (Martinsen, 1990; Willis et al., 1999; Chidsey et al., 2004; Olariu and Bhattacharya, 2006; Gani and Bhattacharya, 2007; Porebski and Steel, 2006; Enge et al., 2010; Ahmed et al., 2014; Gugliotta et al., 2015).

Mouth bars can be classified according to two main schemes that are based on the main sedimentary depositional and reworking processes considered important in their construction:

537 the fluvial-, tidal-, and wave-dominated classification of Galloway (1975), or the buoyancy-, 
friction-, and inertia-dominated classification of Bates (1953) and Wright (1977). The former has received considerably more attention in the literature because evidence for (the relative roles of) tidal and wave activity can be readily reconstructed from sedimentary structures and associated paleoflow indicators in the mouth bar. Conversely, the latter has received little attention because Wright's (1977) classification proposed expected plan-view morphologies for the different types of mouth bar, but not the expected bedforms and sedimentary structures. Even with excellent exposure such as that documented in this study, subtleties in the original plan view geometries of the mouth bars are extremely difficult to reconstruct, and the map views presented in Figures 5 and 7 are considered too crude to use to classify the mouth bars according to either scheme.

By combining sedimentological and architectural data, it is proposed that the mouth bars documented in this study can be ordered flowingly, from least to most friction-dominated: MB1, MB2, MB3 (from the Betsie Shale), and the mouth bar in the Fire Clay Coal Zone. Each was interpreted to have formed in shallower water, from c. $50 \mathrm{~m}$ to $5 \mathrm{~m}$. MB2 and 3 show reduced bed lengths compared to MB1, and these downlap sharply on to MB1. In the mouth bar in the Fire Clay Coal Zone, beds downlap and terminate sharply on the underlying Fire Clay Coal. Short bed lengths (100s m), abrupt downlap and poorly developed bottomsets are architectural features that are likely associated with high bed friction and rapid flow deceleration in relatively shallow water settings (Fig. 8). Conversely, longer bed lengths (kms), gradual tapering of beds and better developed bottomsets are likely characteristic of flows that had or maintained greater inertia.

Sedimentologically, thin beds of the distal mouth bar FA4, displaying normal, inverse, inverse-normal, or a lack of grading, are present in all mouth bars, and are enigmatic in their origin. Similar beds in other prodeltaic successions have been interpreted as hyperpycnal in origin (e.g. Mulder et al., 2003; Soyinka and Slatt, 2008; Zavala et al. 2011), but the occurrence of this facies in the mouth bar in the Fire Clay Coal Zone suggests in this case study they may also be generated by homopycnal flows. Mouth bars MB1-3 do, however, show evidence for deposits that are definitively of hyperpycnal in origin. MB1, displays successions of welldeveloped normally-graded turbidites (FA3) in the frontal lobe, as well as in the lower forests and bottomsets of the mouth bar itself. This suggests that flows were able to maintain or increase their inertia due to the long run-out distances ( $>2 \mathrm{~km})$ at the mouth bar front, and the flows were able to achieve autosuspension (Fig. 7A and B). MB2 and 3 lack turbidites, but like MB1, contain subaqueous terminal distributary channels (FA6) in their topsets and upper forests, indicative of plunging underflows. The absence of turbidites associated with MB2 and 3 can be explained by the fact that they were prograding into shallower water, and frictional deceleration of the hyperpycnal flows prohibited bypass of the mouth bar, and the formation of 
a frontal lobe on the basin floor, or the formation of plumes capable of depositing normallygraded turbidites. The mouth bar in the Fire Clay Coal Zone contains the greatest proportion of (climbing) ripple and trough cross bedding development, and these structures are considered to be most representative of friction-dominated end-members (Turner and Tester, 2006). None of the mouth bars in this study show evidence for currents having become supercritical, so following Wright (1977), none can be interpreted as having been inertia-dominated. This result is important, because it suggests that the formation of a frontal lobe, on the basin floor ahead of the mouth bar itself, in an architectural element that is characteristic of (the maintenance of) significant inertial-forces in the outflowing jet, in an overall friction-dominated setting, but may not necessarily be evidence that the mouth bar was inertia-dominated (Fig. 8).

Documentation of the internal architecture and changes in facies distributions within individual mouth bars also provide evidence for intrinsic mouth bar processes which may not be fully resolved in plan-view "snapshots" of modern systems. For example, in the mouth bar in the Fire Clay coal zone, the upper fining-up succession is evidence for gradually reduced channel discharge upstream, and suggests that mouth bar aggradation had reduced discharge sufficiently to induce "choking", of the feeding distributary channel, and possibly upstream avulsion of the distributary. This fining-upward succession, however, was only deposited on the westerly flank of the mouth bar (Fig. 5B-D), indicating that, additionally, the easterly flank of the mouth bar had become abandoned. This contrasts with typical models for mouth bar evolution, which emphasize the formation of "middle ground bars" (Wright, 1977), where friction at the bed causes rapid flow deceleration and high rates of sedimentation at the river mouth, which in turn reduces channel discharge and forces bifurcation of the distributary channel around both sides of the mouth bar (Elliott, 1986; Olariu and Bhattacharya, 2006; Edmonds and Slingerland, 2007). In this example, growth of the mouth bar instead led to preferential deposition on one flank, whilst simultaneously, upstream avulsion was reducing discharge in the distributary feeding the mouth bar. Later, the channel avulsed again, to the other side of the now abandoned mouth bar, as evidenced by the coal-filled scour to the east (Fig. 4B and 5E). Similar patterns can be determined from satellite imagery of modern analogues for this crevasse delta (e.g. Fig. 5G): even though two simultaneous channels flanking an abandoned mouth bar may be present, the development of active mouth bars downstream from these channels show that only one channel is active at a time, whilst the other may be in a phase of abandonment. Figure $8 \mathrm{~A}-\mathrm{C}$ summarises the possible stratal stacking patterns, coarsening- and fining-up profiles generated in mouth bars experiencing symmetrical lateral growth, and channel bifurcation around the mouth bar, asymmetric lateral growth, with discharge being maintained in a distributary on a single flank of a mouth bar, and upstream avulsion. The observation is important, because the lateral accretion of a mouth bar during abandonment generates a fining-upward trend, which in 
outcrop, core or wireline data may be mistaken for a the deposits of a channel-fill (c.f. discussion in Schomacker et al., 2010). Similar, gradual abandonment of the distributary channel resulted in the upper fining-up succession observed in MB2 in the Betsie Shale (Fig. 6C). The formation of a mouth bars following avulsion has been previously been documented at outcrop by Turner and Tester (2006) and Li and Bhattacharya (2014), and is considered to be characteristic process in deltas that are strongly aggradational, and develop relatively few, larger distributaries on the delta top (Mohrig et al., 2000; Jerolmack and Swenson, 2007). Hence the interpretation that some of the mouth bars in the Upper Breathitt Group record upstream avulsion may shed light on the upstream morphology of the delta top.

A consistent observation from these two case studies is the progressive steepening of clinoform dip angles within a single mouth bar succession, both in depositional dip and strike view. Progressive steepening of clinoform foresets have been described previously from outcrop studies of ancient mouth bars (e.g. Porebski and Steel, 2006; Enge et al., 2010), as well as from seismic surveys of Pleistocene and younger deltas (e.g. Hart and Long, 1996; Roberts et al., 2004). Such "oversteepening" has been ascribed to the build-out of deltas over the shelf edge (Bhattacharya, 2010), but no such shelf edge exists in the case studies documented herein, suggesting that progressive steepening is the product of the progradation of beds that successively thin down dip (Enge et al., 2010), and is therefore an inherent property of mouth bars. This study supports the assertation by Enge et al. (2010) and Gugliotta et al. (2015), that a key criterion for defining the contact between one mouth bar and another, within a mouth bar complex, is the recognition of a surface which demarks lower angle clinoform onlap of the later mouth bar on to the higher angle clinoform of the earlier mouth bar.

When looking at mouth bar complex architecture, in the Betsie Shale, the architectural differences between MB1 and MB2 and 3 (i.e. presence of a frontal lobe in MB1, and an absence in MBs 2 and 3; beds that taper gently with well-developed bottomsets in MB1, but short bed lengths which downlap abruptly with an absence of well-developed bottomsets in MBs 2 and 3), are a function of the shallowing of the water into which they prograded. Since in-filling of accommodation is generated by the deposition of successive mouth bars in a mouth bar complex, it is proposed that a succession of mouth bars that are increasingly friction-dominated is a fundamental intrinsic property of mouth bar complexes. Differences in the sedimentology of MB1 versus MB2 and 3 (i.e. an absence of well-developed turbidites in MBs 2 and 3) may be interpreted similarly.

The mouth bars in the Fire Clay Coal zone, and MB1 and 2 in the Betsie Shale demonstrate initial progradation, followed by lateral accretion and progradation, followed by retrogradation of the locus of deposition during gradual shut-off of the sediment supply (Fig. 5A-D and Fig. 7A-E). From this study, these patterns are considered to represent the normal 
migration of the locus of sediment deposition in friction-dominated mouth bars under conditions of static relative sea/lake level and in relatively unconfined settings, although this conclusion may need to be verified against further studies of mouth bar architecture. Clinoform stacking patterns in MB3 in the Betsie shale, however, imply stronger progradation, reflecting confinement of the mouth bar between MB1 and 2. MB3 represents the complete in-filling of accommodation within the study area, before it became a zone of bypass. These examples illustrate that upward changes in mouth bar architecture and facies distributions within a mouth bar complex, are to a certain degree, a predictable product of shallowing and increasing confinement during delta progradation. They may also offer insight into the stacking patterns and facies distributions that may be expected under dynamic conditions of relative sea/lake level change and sediment supply.

\section{ACKNOWLEDGEMENTS}

This project was funded by Statoil. Thanks to W. Bower, and A. Dawson, for field assistance. J. Koldingsnes and Ø. Spinnangr are thanked for the imagery in Figures 3M, 4C and D. We are grateful for reviews by J. Bhattacharya, C. Olariu and associate editor B. Pratt, that improved the manuscript substantially. The views expressed in the paper are, however, the authors' alone.

\section{REFERENCES CITED}

Adkins, R.M., and Eriksson, K.A., 1998, Rhythmic sedimentation in a mid-Pennsylvanian deltafront succession, Magoffin Member (Four Corners Formation; Breathitt Group), Eastern Kentucky: a near complete record of daily, semi-monthly and monthly tidal periodicities, in Alexander, C.R., Davies, R.A., and Henry, V.J., eds., Tidalites: Processes and Products, SEPM Special Publication 61, p. 85-94.

Ahmed, S., Bhattacharya, J.P., Garza, D.E., and Li, Y., 2014, Facies architecture and stratigraphic evolution of a river dominated delta front, Turonian Ferron Sandstone, Utah, U.S.A.: Journal of Sedimentary Research, v. 84, p. 97-121.

Aitken, J.F., and Flint, S.S., 1994, High-frequency sequences and the nature of incised valley-fills in fluvial systems of the Breathitt Group (Pennsylvanian), Appalachian foreland basin, eastern Kentucky, in Dalrymple, R.W., Boyd, R., and Zaitlin, B., eds., Incised Valley Systems: Origin and Sedimentary Sequences, SEPM Special Publication 51, p. 353-368. 
Aitken, J.F., and Flint, S.S., 1995, The application of high-resolution sequence stratigraphy to fluvial systems: a case study from the Upper Carboniferous Breathitt Group, eastern Kentucky, USA: Sedimentology, v. 42, p. 3-30.

Alvord, D.C., 1965, Geologic Map of the Broad Bottom Quadrangle, Eastern Kentucky: U.S. Geological Survey, 7.5-Minute Geological Quadrangle Map, GQ-442, scale 1:24000, 1 sheet. Alvord, D.C., and Holbrook, C.E., 1965, Geological map of the Pikeville quadrangle, Pike and Floyd Counties, Kentucky: U.S. Geological Survey, 7.5-Minute Geological Quadrangle Map GQ 480, scale 1:24000, 1 sheet.

Bates, C.D., 1953, Rational theory of delta formation: Bulletin of the American Association of Petroleum Geologists, v. 37, p. 2119-2162.

Bhattacharya, J.P., 2006, Deltas, in Posamentier, H.W., and Walker, R.G., eds., Facies Models Revisited, SEPM Special Publication 84, p. 237-292.

Bhattacharya, J.P., 2010, Deltas, in James, N.P. and Dalrymple, R.W., eds., Facies Models 4, Geological Association of Canada, p. 233-264.

Bhattacharya, J.P., and MacEachern, J.A., 2009, Hyperpycnal rivers and prodeltaic shelves in the Cretaceous seaway of North America: Journal of Sedimentary Research, v. 79, p. 184-209.

Bouma, A.H., 1962, Sedimentology of Some Flysch Deposits: Amsterdam, Elsevier, 168 p.

Chesnut, D.R., 1994, Eustatic and tectonic control of the lower and middle Pennsylvanian strata of the central Appalachian Basin, in Dennison, J.M. and Ettensohn, F.R., eds., Tectonic and Eustatic Controls on Sedimentary Cycles, SEPM Concepts in Sedimentology and Paleontology 4, p. 25-34.

Chesnut, D.R., 1996, Geologic framework for the coal-bearing rocks of the Central Appalachian Basin: International Journal of Coal Geology, v. 31, p. 55-66.

Chesnut, D.R., 1991, Paleontological Survey of Pennsylvanian Rocks of the Eastern Kentucky Coal Field: Kentucky Geological Survey Information Circular, 11 th Series, no. 36, $71 \mathrm{p}$. Chesnut, D.R., 1992, Stratigraphic and Structural Framework of the Carboniferous rocks of the Central Appalachian Basin: Kentucky Geological Survey Bulletin, 11 th Series, no. 3, 42 p.

Chidsey, T.C., Adams, R.D., and Morris, T.H., 2004, The fluvial-deltaic Ferron Sandstone: Regional-to-Wellbore-scale Outcrop Analog Studies and Allpications to Reservoir Modelling: American Association of Petroleum Geologists Studies in Geology 50, 568 p. Coleman, J.M., and Wright, L.D., 1975, Modern river deltas: variability of processes and sand bodies, in Broussard, M., ed., Deltas, Models for Exploration, Houston, Houston Geological Society, p. 99-149.

Dalrymple, R.W., 2010, Tidal depositional systems, in James, N. and Dalrymple, R.W. eds., Facies Models 4, Geological Association of Canada, p. 201-231. 
Driscoll, N.W., and Karner, G.D., 1999, Three-dimensional quantitative modeling of clinoform development: Marine Geology, v. 154, p. 383-398.

Edmonds, D. a., and Slingerland, R.L., 2007, Mechanics of river mouth bar formation: Implications for the morphodynamics of delta distributary networks: Journal of Geophysical Research F: Earth Surface, v. 112, p. F02034.

Elliott, T., 1986, Deltas, in Reading, H.G. ed., Sedimentary Environments and Facies, Oxford, U.K., Blackwell Scientific Publications, p. 113-154.

Emms, P.W., 1999, On the ignition of geostrophically rotating turbidity currents: Sedimentology, v. 46, p. $1049-1063$.

Enge, H.D., Howell, J. a., and Buckley, S.J., 2010, The Geometry and Internal Architecture of Stream Mouth Bars in the Panther Tongue and the Ferron Sandstone Members, Utah, U.S.A.: Journal of Sedimentary Research, v. 80, p. 1018-1031.

Englund, K.J., and Thomas, R.E., 1990, Late Paleozoic depositional trends in the central Appalachian Basin: U.S. Geological Survey Bulletin, v. 1839, p. F1-F19.

Ferm, J.C., 1970, Allegheny deltaic deposits, in Morgan, J.P., ed., Deltaic sedimentation: Modern and ancient: SEPM Special Publication 15, 312 p.

Ferm, J.C., and Cavaroc, V.V., 1968, A nonmarine sedimentary model for the Allegheny rocks of West Virgina, in Klein, G. de V.G., ed., late Paleozoc and Mesozoic Continental Sedimentation, northeastern North America: Geological Society of America Special Paper 106, p. 1-19.

Fielding, C.R., Trueman, J.D., and Alexander, J., 2006, Holocene Depositional History of the Burdekin River Delta of Northeastern Australia: A Model for a Low-Accommodation, Highstand Delta: Journal of Sedimentary Research, v. 76, p. 411-428.

Fielding, C.R., Trueman, J.D., and Alexander, J., 2005, Sedimentology of the modern and Holocene Burdekin River Delta of north Queensland, Australia; controlled by river output, not by waves and tides: SEPM Special Publication 83, p. 467-496.

Galloway, W.D., 1975, Process Framework for describing the morphologic and stratigraphic evolution of deltaic depositional systems, in Broussard, M.L., ed., Deltas, Models for Exploration, p. 86-98.

Gani, M.R., and Bhattacharya, J.P., 2007, Basic Building Blocks and Process Variability of a Cretaceous Delta: Internal Facies Architecture Reveals a More Dynamic Interaction of River, Wave, and Tidal Processes Than Is Indicated by External Shape: Journal of Sedimentary Research, v. 77, p. 284-302.

Gradstein, F.M., Ogg, J.G., Schmitz, M.D., and Ogg, G.M., 2012, The Geologic Time Scale: Oxford, Elsevier, $1144 \mathrm{p}$. 
Greb, S.F., and Archer, A.W., 1995, Rhythmic sedimentation in a mixed tide and wave deposit, Hazel patch Sandstone (Pennsylvanian), Eastern Kentucky Coal Field: Journal of Sedimentary Research, v. 65, p. 96-106.

Greb, S.F., and Chesnut, D.R., 1996, Lower and lower Middle Pennsylvanian fluvial to estuarine deposition, central Appalachian basin: Effects of eustasy, tectonics, and climate: Bulletin of the Geological Society of America, v. 108, p. 303-317.

Greb, S.F., Chesnut, D.R., Eble, C.F., and Blake, B.M., 2008, The Pennsylvanian of the Appalachian Basin, in Greb, S.F. and Chesnut, D.R. eds., Carboniferous Geology and Biostratigraphy of the Appalachian Basin: Special Publication of the Kentucky Geological Survey 10, p. 32-45. Greb, S.F., and Martino, R.L., 2005, Fluvial-estuarine transitions in fluvial-dominated successions: examples from the Lower Pennsylvanian of the central Appalachian Basin, in Blum, M.D., Marriott, S.B., and Leclair, S., eds., Fluvial Sedimentology VII: Special Publication of the International Association of Sedimentologists 35, p. 425-452.

Greb, S.F., Pashin, J.C., Martino, R.L., and Eble, C.F., 2008, Appalachian sedimentary cycles during the Pennsylvanian: Changing influences of sea-level, climate and tectonics, in Fielding, C.R., Frank, T.D., and Isbell, J.L., eds., Resolving the Late Palaeozoic Ice Age in Time and Space: Geological Society of America Special Paper 441, p. 235-248.

Gugliotta, M., Flint, S.S., Hodgson, D.M., and Veiga, G.D., 2015, Stratigraphic record of riverdoinated crevasse subdeltas with tidal influence: Journal of Sedimentary Research, v. 85, p. 265-284.

Hart, B.S., and Long, B.F., 1996, Forced regressions and lowstand deltas: Holocene Canadian example: Journal of Sedimentary Research, v. 66, p. 820-829.

Van Heerden, I.L., and Roberts, H.H., 1988, Facies development of Atchafalaya delta, Louisiana: a modern bayhead delta: Bulletin of the American Association of Petroleum Geologists, v. 72, p. $439-453$.

Horne, J.C., Ferm, J.C., Caruccio, F.T., and Baganz, B.P., 1978, Depositional models in coal exploration and mine planning in the Appalachilan Region: Bulletin of the American Association of Petroleum Geologists, v. 62, p. 2739-2411.

Jerolmack, D.J., and Swenson, J.B., 2007, Scaling relationships and evolution of distributary networks on wave-influenced deltas: Geophysical Research Letters, v. 34, L23402.

Jerrett, R.M., Flint, S.S., and Brunt, R.L. (in review) Palaeovalleys in foreland ramp settings - what happens when accommodation decreases down-dip: Basin Research.

Julien, P.Y., 2002, River Mechanics: Cambridge, U.K., Cambridge University Press, 434 p.

Lamb, M.P., and Mohrig, D., 2009, Do hyperpycnal-flow deposits record river-flood dynamics?: Geology, v. 37, p. 1067-1070. 
Leeder, M.R., 1973, Fluviatile fining-upwards cycles and the magnitude of palaeo-channels: Geological Magazine, v. 110, p. 265-276.

Li, Y., and Bhattacharya, J., 2014, Facies architecture of asymmetrical branching distributary channels: Cretaceous Ferron Sandstone, Utah, USA: Sedimentology, v. 61, p. 1452-1483.

MacEachern, J.A., 2010, Ichnology and facies models, in James, N.P. and Dalrymple, R.W., eds., Facies Models 4, Geological Association of Canada, p. 19-58.

Martino, R.L., 1994, Facies analysis of Middle Pennsylvanian marine units, southern West Vrigina, in Rice, C.L., ed., Elements of Pennsylvanian Stratigraphy, Central Appalachian Basin: Geological Society of America Special Paper 294, p. 69-86.

Martino, R.L., 1996, Stratigraphy and depositional environments of the Kanawha Formation (Middle Pennsylvanian ), West Virginia: International Journal of Coal Geology, v. 31, p. 217-248.

Martinsen, 0.J., 1990, Fluvial, inertia-dominated deposition in the Namurian (Carboniferous) of northern England: Sedimentology, v. 37, p. 1099-1113.

Miall, A.D., 1976, Facies Models, 4. Deltas: Geoscience Canada, v. 3, p. 215-227.

Mitchum, R.M., and Van Wagoner, J.C., 1991, High-frequency sequences and their stacking patterns: sequence-stratigraphic evidence of high-frequency eustatic cycles: Sedimentary Geology, v. 70, p. 131-147, 153-160.

Mohrig, D., Heller, C., Paola, C., and Lyons, W.J., 2000, Interpreting avulsion processes from ancient alluvial sequences: Guadalope Matarranya system (northern Spain) and Wasatch Formation (western Colorado): Geological Society of America Bulletin, v. 112, p. 17871803.

Mulder, T., and Syvitski, J.P.M., 1995, Turbidity Currents Generated at River Mouths during Exceptional Discharges to the World Oceans: The Journal of Geology, v. 103, p. 285-299.

Mulder, T., Syvitski, J.P.M., Migeon, S., Faugeres, J.-C., and Savoye, B., 2003, Marine hyperpycnal flows: initiation, behavior and related deposits. A review: Marine and Petroleum Geology, v. 20, p. 861-882.

Mutti, E., Tinterri, R., Benevelli, G., Di Biase, D., and Cavanna, G., 2003, Deltaic mixed turbidite sedimentation of ancient foreland basins: Marine and Petroleum Geology, v. 20, p. 733-755.

Nadon, G.C., 1998, Magnitude and timing of peat-to-coal compaction: Geology, v. 26, p. 727-230.

Olariu, C., and Bhattacharya, J.P., 2006, Terminal distributary channels and delta front architecture of river-dominateddelta systems: Journal of Sedimentary Research, v. 76, p. $212-233$.

Olariu, C., Bhattacharya, J.P., Xu, X., Aiken, C.L.V., Zeng, X., and McMechan, G.A., 2005, Integrated study of ancient delta front deposits, using outcrop, ground penetrating radar and three dimension photorealistic data: Cretaceous Panther Tongue sandstone, Utah, in Giosan, L. 

Publication 83, p. 155-178.

Orton, G.J., and Reading, H.G., 1993, Variability of deltaic processes in terms of sediment supply,

Postma, G., 1995, Causes of architectural variations in deltas, in Colella, L.A., and Prior, D.B., eds., Parker, G., 1982, Conditions for the ignition of catastrophically erosive turbidity currents: Marine Geology, v. 46, p. 307-327.

Porebski, S.J., and Steel, R.J., 2006, Deltas and sea-level change: Journal of Sedimentary Research, v. 76, p. 390-403.

Postma, G., 1990, Depositional architecture and facies of river and fan deltas: a synthesis, in Colella, A., and Prior, D.B., eds., Coarse-Grained Deltas: International Association of Sedimentologists Special Publication 10, p. 13-27.

Puffett, W.P., 1964, Geology of the Hazard South Quadtrangle, Kentucky: U.S. Geological Survey, 7.5-Minute Geological Quadrangle Map, GQ 343, scale 1:24000, 1 sheet.

Quinlan, G.M., and Beaumont, C., 1984, Appalachian thrusting, lithospheric flexure, and the Paleozoic stratigraphy of the eastern interior of North America: Canadian Journal of Earth Sciences, v. 21, p. 973-996.

Reading, H.G., and Levell, B.K., 1996, Controls on the sedimentary rock record, in Reading, H.G. ed., Sedimentary environments: processes, facies and stratigraphy, Oxford, U.K., Blackwell Science, p. 5-36.

Rice, C.L., and Hiett, J.K., 1994, Revised correlation chart of coal beds, coal zones and key stratigraphic units in the Pennsylvanian rocks of eastern Kentucky: U.S. Geological Survey Miscellaneous Field study, 1 sheet.

Rice, C.L., Sable, E.G., Dever, Jr., G.R., and Kehn, T.M., 1979, The Mississippian and Pennsylvanian (Carboniferous) systems in the United States - Kentucky: U.S. Geological Survey Professional Paper 1110-F, p. F1-F32.

Rich, J., 1951, Three critical environments of deposition, and criteria for recognition of rocks deposited in each of them: Geological Society of America Bulletin, v. 62, p. 1-19.

Roberts, H.H., Fillion, R.H., Kohl, B., Robalin, J.M., and Sydow, J.C., 2004, Depositional architecture of the Lagniappe Delta; sediment characteristics, timing of depositional events, and temporal relationships with adjacent shelf-edge deltas, in Anderson, J.B., and Fillion, R.H., eds., Late Quaternary Stratigraphic Evolution of the Northern Gulf of Mexico Margin: SEPM Special Publication 79, p. 143-188. 
Ryer, T.A., and Langer, A.W., 1980, Thickness change involved in the peat-to-coal transformation for a bituminous coal of Cretaceous age in central Utah: Journal of Sedimentary Petrology, v. 50, p. 987-992.

Schomaker, E.R., Kjemperud, A.V, Nystuen, J.P., and Jahren, J.S., 2010, Recognition of sharp-based mouth-bar deposits in the Eocene Green River Formation, Unita Basin, Utah: Sedimentology, v. 57, p. 1069-1087.

Soyinka, O.A., and Slatt, R.M., 2008, Identification and micro-stratigraphy of hyperpycnites and turbidites in Cretaceous Lewis Shale, Wyoming: Sedimentology, v. 55, p. 1117-1133.

Staub, J.R., and Cohen, A.D., 1978, The Snuggedy Swamp of South Carolina: a back barrier estuarine coal-forming environment: Journal of Sedimentary Petrology, v. 49, p. 113-143.

Tankard, A.J., 1986, Depositional response to foreland deformation in the Carboniferous of eastern Kentucky: Bulletin of the American Association of Petroleum Geologists, v. 70, p. 853-868.

Taylor, A.M., and Goldring, R., 1993, Description and analysis of bioturbation and ichnofabric: Journal of the Geological Society [London], v. 150, p. 141-148.

Thomas, W.A., 1976, Evolution of the Ouachita-Appalachian continental margin: The Journal of Geology, v. 84, p. 323-342.

Thomas, R.G., Smith, D.G., Wood, J., Visser, J., Calverley-Range, E.A., and Koster, E., 1987, Inclined heterolithic statification - terminology, description, interpretation and significance: Sedimentary Geology, v. 53, p. 123-179.

Turner, B.R. and Tester, G.N., 2006, The Table Rocks Sandstone: A fluvial, friction-dominated lobate mouth bar sandbody in the Westphalian B Coal Measures, NE England: Sedimentary Geology, v. 190, p. 97-119.

Van Asselen, S., Strouthamer, E., and Van Asch, T.W.J., 2009, Effects of peat compaction on delta evolution: a review on processes, responses, measuring and modeling: Earth-Science Reviews, v. 92, p. 35-51.

Van Asselen, S., Strouthamer, E., and Smith, N.D., 2010, Factors controlling peat compaction in alluvial floodplains: A case study in the cold-temperate umberland Marshes, Canada: Journal of Sedimentary Research, v. 80, p. 155-166.

Wanless, H.R., 1975, Appalachian region, in McKee, E.D., and Crosby, E.J., eds., Paleotectonic investigations of the Pennsylvanian System in the United States, U.S. Geological Survey Professional Paper 853, p. 17-62.

Willis, B.J., Bhattacharya, J.P., Gabel, S.L., and White, C.D., 1999, Architecture of a tide-infuenced delta in the Frontier Formation of Central Awyoming, USA: Sedimentology, v. 46, p. 667688. 
Wright, L.D., 1977, Sediment transport and deposition at river mouths: a synthesis: Bulletin of the Geological Society of America, v. 88, p. 867-868.

Wright, L.D., and Coleman, J.M., 1973, Variations in morphology of major river deltas as functions of ocean wave and river discharge regimes: Bulletin of the American Association of Petroleum Geologists, v. 57, p. 370-398.

Wright, L.D.Ã., and Friedrichs, C.T., 2006, Gravity-driven sediment transport on continental shelves: a status report: Continental Shelf Research, v. 26, p. 2092-2107.

Zavala, C., Arcuri, M., Meglio, M. Di, Diaz, H.G., and Contreras, C., 2011, A Genetic Facies Tract for the Analysis of Sustained Hyperpycnal Flow Deposits, in Slatt, R.M., and Zavala, C., eds., Sediment transfer from shelf to deep water - revisiting the delivery system: AAPG Studies in Geology 61, p. 31-51.

FIGURE AND TABLE CAPTIONS

Figure 1. (A) Location of the preserved Pennsylvanian-early Permian succession of the greater Appalachian Basin, and frontal thrust of the Alleghanian Orogeny. Inset, location map in the contiguous U.S.A. (B) Outcrop map of the Breathitt Group in eastern Kentucky, showing isopach of the combined Pikeville and Hyden formations (from Jerrett et al., accepted). The locations of detailed maps illustrating the position of collected sedimentary logs, and photomosaics used to document mouth bar complexes in this study, (C) and (D), are boxed. Abbreviation: IPCFZ=Irvine-Paint Creek Fault System. (C) Study area of the mouth bar in the Fire Clay Coal zone along Ky. 7 between Viper and Jeff, Perry County. The dashed box represents the area shown in Figures 5A-E. (D) Study area of the mouth bar in the Betsie Shale exposed along U.S. 23 and side-roads in the Pikeville area, Pike County.

Figure 2. (A) Chronostratigraphy and lithostratigraphy of the Pennsylvanian foreland basin succession of the central Appalachian Basin in eastern Kentucky. Based on data from Greb et al. (2008), but recalibrated to the timescale of Gradstein et al. (2012). Abbreviations: AC Fm. = Alvy Creek Formation; BC Fm. = Bottom Creek Formation; BR Sst. = Bee Rock Sandstone; WP Sst. = Warren Point Sandstone; S Sst. = Sewanee Sandstone; (B) Named coals and major marine units of the extensively exposed Pikeville and Hyden formations of the upper Breathitt Group. Locally developed coal seams, and shale members are shown with dashed lines and hatched gray, respectively. The stratigraphic positions of the two mouth bar complexes studied in this contribution are shown. 
Figure 3. Representative photographs of facies associations (FA). Location names refer to Fig. 1C and D. (A) FA1, characterized by siltstone interbedded with sideritized thin beds of very fine silty sandstone. Base of the Betsie Shale Member at Location BA-1. Pole is $1 \mathrm{~m}$ long. (B) FA2, illustrating typical dark gray or black, highly organic, laminated claystone and siltstone and rare siderite concretions - S. FA2 overlies the Fire Clay Coal - FA8 - at Location 7-4. Pole is $1 \mathrm{~m}$ long. (C) Detail of FA3, illustrating typical sharp, loaded bases to normally graded fine sandstone beds. Lower portion of the Betsie Shale Member, Location 23-6. Compass clinometer is $10 \mathrm{~cm}$ long. (D) FA3, illustrating the characteristic "clean" appearance of the sand beds in a "dirty" silty matrix. Lower portion of the Betsie Shale Member, Location 23-5. Pole is $1 \mathrm{~m}$ long. (E) Detail of FA4A, illustrating typical inverse-normal grading in a fine to medium grained sandstone bed. Upper part of the Betsie Shale Member, Location 23-2. (F) Characteristically "dirty", poorly sorted nature of siltstone and silty sandstone in FA4A. Upper part of the Betsie Shale Member, Location 3227-1. Compass clinometer is $10 \mathrm{~cm}$ long.

Figure 3 (cont.). (G) FA4B, characterized by paired "thick" beds of fine-medium grained sandstone, with recessive "thin" beds of silty fine sandstone. Organisation of these paired beds into thickening-up-thinning-up-thickening-up successions is typical. FA4B contains "cleaner", better sorted sandstone beds, relative to FA4A. Upper part of the Betsie Shale, Location 3227-4. Compass clinometer is $10 \mathrm{~cm}$ long. (H) Detail of FA5, displaying tabular cross bedded medium grained sandstone, and homogenous successions of ripple cross laminated fine to medium sandstone. Mouth bar in the Fire Clay Coal zone, Location 7-2. Red taped area of pole in bottom left of photograph is $10 \mathrm{~cm}$ long. (I) In FA5, the trace of soft sediment fold axial planes - AP - indicate down paleoslope vergence to the NW (left), and folds are truncated by sharp-based plane bedded and ripple cross-laminated successions of fine and medium grained sandstone. Upper part of the Betsie Shale, Location 3227-2. (J) FA6 is characterized by sharp, scour-based - SB - trough cross bedded - TCB - medium to coarse sandstone beds that sometimes amalgamate to form multi-storey sand bodies. The storey contact - SC - is marked. Upper part of the Betsie Shale, Location 3227-1. (K) FA6, sharp, scour-based trough cross bedded channel-fills C1 to C6 - pass laterally into "wings" of FA4. Channel-fills stack compensationally, and are separated by several beds of FA4. Upper part of the Betsie Shale, Location 23-2. (L) Characteristic weathering texture of FA7. Rootlet traces, or larger stigmarian root trunks of Lycopsid trees are common. Upper part of the Betsie Shale, Location 23-11. 
Figure 3 (cont.). (M) Photograph and summary sketch of the architecture of FA9. The channel body comprises two erosively-based fining-up storeys - S1 and S2 - of sandstone and heteroliths. In the lower part of S1, sandstone dominated bedsets cross-cut each other, and sequentially truncate and define the base of the storey. Above this, scourbased heterlothic beds dip broadly concordantly and downlap on to the lower succession and define IHS (Thomas et al., 1987). Bedding in IHS is offset by a succession of listric normal faults that dip concordantly with bedding and represent point-bar failure. The sand body is within the Fire Clay Coal zone at Location 7-1. Coeval levee deposits - L - fine away from the channel margin. Person boxed in the photograph for scale.

Figure 4. (A) Oblique strike section through the Fire Clay Coal Zone along Ky. 7. (B) Oblique strike section through the mouth bar in the Fire Clay Coal Zone, corrected for post-depositional deformation by using the top of the main Fire Clay Coal as a datum. Clinoform bedding in the lower coarsening-up succession displays bidirectional downlap on to the main Fire Clay Coal. In the upper fining-up succession, clinoform bedding displays apparent dip to the SW, downlapping on to the Fire Clay Coal, and successively offlapping towards the SW. Note that bedding and normal faults dip towards the SE in FA8 at Location 7-1. (C) Coarsening-up (progradation-aggradation) to fining-up (abandonment) succession of the mouth bar at the NE end of Location 7-2. The mouth bar is truncated to the $W$ by an erosion surface at the base of a channel, abandoned and now filled by the upper coal of the Fire Clay Coal zone. (D) Downlap and offlap of the fining-up succession, at the SE end of Location 7-2. This represents lateral bar accretion during abandonment of the mouth bar. Person boxed for scale. Abbreviations: $\mathbf{F C}_{M}=$ Main Fire Clay coal; $\mathrm{FC}_{\mathrm{R}}=$ upper coal of the Fire Clay Coal zone; $\mathrm{m}_{\mathrm{P}}=$ mean azimuth of measured paleoflow, $m_{\mathrm{B} / \mathrm{F}}=$ mean dip azimuth of measured bedding or fault plane; $\mathbf{n}=$ number of readings taken.

Figure 5. (A-E) Plan view evolution of the mouth bar in the Fire Clay Coal Zone. (A) Mouth bar initiation. (B) Progradation and weak lateral accretion to the west. (C) Gradual abandonment, retrogradation and lateral accretion to the west. (D-E) Abandonment and avulsion of the distributary channel to the east of the mouth bar. Substantial deposition of sediment occurred away from the mouth bar, through settling of hypopycnal silt and clay plumes. Width and meander geometry of the trunk/distributary channel is taken from the generalized relationships between unconfined meandering fluvial channel bankfull depth (storey height) and width (Leeder, 1973), and channel width and meander wavelength and radius of curvature (Julien, 2002), and is shown for illustrative 
purposes only. The area of the map is shown in Figure 1C. (F-G) Example analogues for the crevasse subdelta mouth bar in the Fire Clay Coal zone from the flood plain of the Columbia River, British Columbia, Canada. (F) Example of a first order mouth bar that

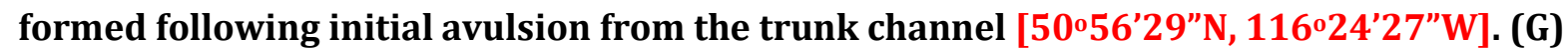
Examples of first to fifth order mouth bars. A second order mouth bar is formed following initial bifurcation around a first order mouth bar, and so on. Note that no mouth bars have formed to the west of the mouth bar labelled $\mathrm{MB}_{3}$. The channel has not bifurcated symmetrically around the mouth bar, and most discharge and sediment load is deflected to the east [50॰50'16”N, 116 18'16"W]. Abbreviations: MB = Mouth bar; L = Levee.

Figure 6. (A) All paleoflow measurements from the Betsie Shale Mouth Bar Complex, demonstrating a bimodal distribution, but with outflow dominance towards the $\mathrm{NW}$ or WNW. Colors refer to the facies association from which the paleoflow measurements were taken (c.f. Fig. 4). (B) Oblique strike section through the Betsie Shale along U.S. 23. (C) Oblique strike section through the Betsie Shale along U.S. 23, corrected for postdepositional deformation by using the base of the Lower Elkhorn Coal as a datum. Clinoform apparent dips are towards the $\mathrm{N}$ in Mouth Bar 1, and to the $\mathrm{S}$ in Mouth Bar 2. (D) The entire Betsie Shale at Location 23-11. Clinoform bedding in Mouth Bar 2, with apparent dips towards the $\mathrm{N}$ are evident relative to the paleohorizontal crevasse splay and levee strata below the Lower Elkhorn Coal. See Figure 4 for key. Abbreviations, BC = Upper Coal of Bingham Coal Zone; C = Clinoform bedding; FA6 = Facies Association 6, terminal distributary channels; $\mathrm{LEC}=$ Lower Elkhorn Coal; $\mathrm{MB}=$ Mouth bar; $\mathrm{m}_{\mathrm{P}}=$ mean azimuth of measured paleoflow; $\mathbf{n}=$ number of readings taken.

Figure 6 (cont.). (E) Oblique dip section through the Betsie Shale along Ky. 3227. (F) Oblique dip section through the mouth bar complex in the Betsie Shale along Ky. 3227, corrected for structural deformation by using the base of the Lower Elkhorn Coal as a datum. Clinoform bedding dips are towards the NW in the upper part of Mouth Bar 2. (G) Steep (c. $2^{\circ}$ ) clinoform bedding, relative to the paleohorizontal crevasse splay and levee strata below the Lower Elkhorn Coal at Location 3227-5. (H) Oblique dip section through the Betsie Shale along U.S. 119. (I) Oblique dip section through the Betsie Shale along U.S. 119 , corrected for structural deformation by using the base of the Lower Elkhorn Coal as a datum. (J) Upper part of Mouth Bar 2, illustrating the NW progradation of FA5 dunes over FA4 in the mouth bar, followed by the deposition of floodplain heteroliths (FA7) and peat (FA8). The latter represent topset strata. See Figure 4 for key. Abbreviations: FA = 
Facies association; $\mathrm{MB}=$ Mouth bar; $\mathrm{m}_{\mathrm{P}}=$ mean azimuth of measured paleoflow; $\mathrm{m}_{\mathrm{AP}}=$ mean dip azimuth of fold axial plane; $\mathbf{n}=$ number of readings taken.

Figure 7. Plan view evolution of in the mouth bar complex in the Betsie Shale. (A-C) Progradation and lateral accretion of MB1 in the southern part of the study area. (D-E) Retrogradation of MB1. Progradation and lateral accretion of MB2 in the northern part of the study area. (F) Progradation of MB3 in a confined setting between MB1 and MB2. See Fig. 5 for key. The area of the map is the same as shown in Figure 1D.

Figure 8. Controls on the architecture of mouth bars recognised in this study. (A) to (D) represent end member friction-dominated mouth bars. In (A), following deposition of the initial bar form at the river mouth discharge is maintained symmetrically either side, leading to symmetrical lateral expansion (accretion) until the distributary bifurcates either side of the mouth bar. This leads to a symmetric concave-up strike geometry and a uniform coarsening-up succession. In (B), discharge occurs preferentially on one flank of the mouth bar leading to asymmetric lateral accretion. The distributary may subsequently prograde to one side or the other of the mouth bar. This generates a coarsening-up succession on the margin of the mouth bar demonstrating lateral accretion, and a fining-up succession on the margin of the mouth bar that represents abandonment. In (C), upstream avulsion results in the gradual abandonment of the mouth bar, generating a fining-up succession above the initial coarsening-up succession. (A) and (D) contrast the depositional strike and dip architectures of a friction-dominated end-member mouth bar, with (E) and (F), the depositional strike and dip architectures of n inertia-influenced, friction-dominated mouth bar. In (A) and (D), beds downlap abruptly on to substrata, bed lengths are short, with poorly developed bottomsets. In $€$ and $(F)$, the succession is characterised by two coarsening-up succession, the lower representing the detached basin floor frontal that prograded ahead of the mouth bar. Beds tape gently, with well-developed bottomsets. Note difference in scale between A-D and $\mathrm{E}-\mathrm{F}$.

Table 1. Summary characteristics of the facies associations recognized in this study. Trace fossil abundance is expressed in terms of the Bioturbation Index (BI; Taylor and Goldring, 1993; MacEachern, 2010).

Appendix 1. Key sedimentary log data collected through the two mouth bar complexes reported in this study. Logs through (A) the crevasse mouth bar in the Fire Clay Coal Zone 
along Ky. 7, corrected for post-depositional deformation by using the top of the main Fire Clay Coal as a datum; (B) the Betsie Shale mouth bar complex along U.S. 23, corrected for post-depositional deformation by using the base of the Lower Elkhorn Coal as a datum;

1071 (C) the Betsie Shale mouth bar complex along Ky. 3227, corrected for post-depositional 1072 deformation by using the base of the Lower Elkhorn Coal as a datum; (D) the Betsie Shale 1073 mouth bar complex along U.S. 119, corrected for post-depositional deformation by using 1074 the base of the Lower Elkhorn Coal as a datum. Note that not all sedimentary logs 1075 collected (c.f. Fig. 1) are shown here. 